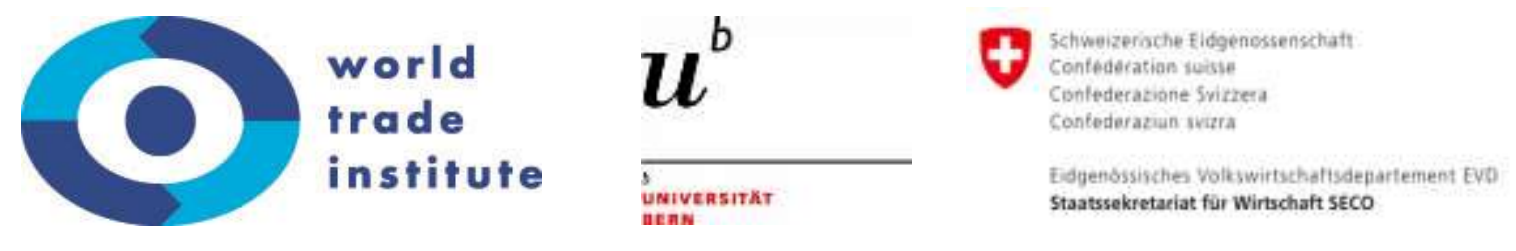

\title{
Disabling Labeling: The WTO Consistency of the Indonesian Mandatory Halal Labeling Law
}

\author{
Michelle Limenta \\ Center for International Trade and Investment \\ Universitas Pelita Harapan \\ michelle.limenta@uph.edu
}

Bayan Edis

Visiting Researcher Center for International Trade and Investment

Universitas Pelita Harapan

\author{
Oscar Fernando \\ Research Associate Center for International Trade and Investment \\ Universitas Pelita Harapan \\ oscar.fernando@uph.edu
}

Abstract

The Halal Act is the first law in Indonesia, a Muslim majority nation requiring Halal certification and labeling. Prior to the law, the Indonesian Council of Ulama (MUI) oversaw voluntary Halal certification. While Islamic organizations in Indonesia have praised the emergence of this law, local and foreign business entities have expressed their anxiety over whether such requirements would mean extra costs for them. The Halal Act involves several WTO issues, which could raise questions of Indonesia's compliance with its WTO obligations. There have been a number of WTO cases where panel and the Appellate Body evaluated the concept of 'public morals'. The question is how to balance this moral/religious objective and the means used to achieve such objective so that they are not more trade restrictive than necessary? It is also important to note that although Indonesia has the largest Muslim population in the world, the Indonesian constitution itself specifies that the country is not a Muslim nation and recognizes the existence of more than five religions in the country. This paper seeks to examine the WTO TBT consistency of the new Indonesian Halal Act and whether mandatory halal certification and labeling can be defended as an exception to WTO law.

Research for this paper was funded by the Swiss State Secretariat for Economic Affairs under the SECO / WTI Academic Cooperation Project, based at the World Trade Institute of the University of Bern, Switzerland.

SECO working papers are preliminary documents posted on the WTI website (www.wti.org) and widely circulated to stimulate discussion and critical comment. These papers have not been formally edited. Citations should refer to a "SECO / WTI Academic Cooperation Project" paper with appropriate reference made to the author(s).

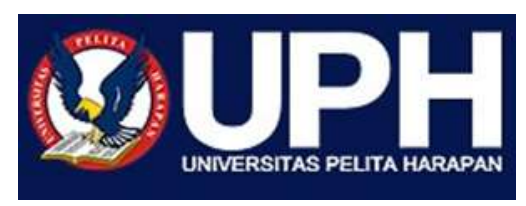




\title{
Disabling Labeling: The WTO Consistency of the Indonesian Mandatory Halal Labeling Law
}

\author{
Michelle Limenta, Bayan Edis, Oscar Fernando*
}

\begin{abstract}
The Halal Act is the first law in Indonesia, a Muslim majority nation requiring Halal certification and labeling. Prior to the law, the Indonesian Council of Ulama (MUI) oversaw voluntary Halal certification. While Islamic organizations in Indonesia have praised the emergence of this law, local and foreign business entities have expressed their anxiety over whether such requirements would mean extra costs for them. The Halal Act involves several WTO issues, which could raise questions of Indonesia's compliance with its WTO obligations. There have been a number of WTO cases where panel and the Appellate Body evaluated the concept of 'public morals'. The question is how to balance this moral/religious objective and the means used to achieve such objective so that they are not more trade restrictive than necessary? It is also important to note that although Indonesia has the largest Muslim population in the world, the Indonesian constitution itself specifies that the country is not a Muslim nation and recognizes the existence of more than five religions in the country. This paper seeks to examine the WTO TBT consistency of the new Indonesian Halal Act and whether mandatory halal certification and labeling can be defended as an exception to WTO law.
\end{abstract}

Key words: Halal, Labelling, Mandatory, Indonesia, TBT, Non-Discrimination, Legitimate Objective, Public Morals, International Standards.

\section{Introduction}

For a majority of Muslim consumers, Halal is an important part of their daily lives as they strive to live according to the principles of Sharia law.

'Halal' is an Arabic word meaning permissible or lawful according to Sharia law. ${ }^{1}$ In the past, Halal was mostly confined to food and food-related products. ${ }^{2}$ However, as the market rapidly grows, Halal industry has expanded beyond food sectors, including pharmaceuticals, cosmetics, logistics, personal care and services such as financial and tourism.

One way to ensure consumers that a product is Halal is by placing a Halal logo. The logo/label is generally issued by a certifying body and it can only be used/placed on a product if the product has been certified Halal. ${ }^{3}$ There are also some producers who decide to not go for certification, but claim that their products are Halal ('self-proclaimed Halal'). Halal certification plays a significant role in global trade. The global Halal market is worth about US \$2.3 trillion dollars and reflects a huge demand for Halal products and Halal industry globally. ${ }^{4}$ Accordingly, countries, like Indonesia, must find a way to juggle the regulation of Halal

\footnotetext{
* The authors are, respectively, Director, Visiting Researcher and Research Associate at the Center for International Trade and Investment, Universitas Pelita Harapan. The authors wish to acknowledge the generous support of Switzerland State Secretariat for Economic Affairs (SECO), the World Trade Institute (WTI) and the WTO Chairs Programme. The usual disclaimer applies.

${ }^{1}$ Ludwig W. Adamec, Historical Dictionary of Islam (Maryland: Scarecrow Press, 2009) 115.

${ }^{2}$ Global Islamic Finance Report, 'The Global Halal Industry: An Overview', Chapter 13, 2013, at 140, http://www.gifr.net/gifr2013/ch_13.PDF.

${ }^{3}$ Halal Choices Australia, 'What is Halal?', http://www.halalchoices.com.au/what_is_halal.html.

${ }^{4}$ Organization of Islamic Countries, 'Forum on unifying halal standards and procedures kicks off at OIC General Secretariat, Jeddah, 9 December 2015, http://www.oicoci.org/oicv3/topic/?t_id=10714\&ref=4218\&lan=en.
} 
certification in such a way as to aid and not hinder trade, while protecting consumers and faithfully reflecting the values of the national population.

In September of 2014, the Indonesian House of Representatives sought to do just that. It passed a new law requiring mandatory Halal certification and labeling on a broad range of products, including 'goods and/or services that are related to foods, beverages, as well as consumer goods that are worn, used or utilized by the public' (Article 1 of the Halal Act). The Halal Product Assurance Act (Halal Act) is the first law in the Muslim majority nation requiring Halal labeling. Prior to this law, the Indonesian Council of Ulama (MUI) oversaw voluntary Halal labeling as primarily an assurance and marketing, rather than legal, approach for Muslim consumers. The new law provides for a 5-year grace period for application, meaning that traders have until 2019 before the mandatory Halal labeling takes full effect.

The Halal Act, while possessing important elements, creates problematic barriers for international trade. Its provisions go too far in requiring Halal certification and Halal and Haram labeling for trade in almost all consumer goods. Among WTO member nations, Indonesia is unique in the lengths this law goes to require both Halal and Haram labeling. The Halal Act, in its current form, has the potential to severely restrict trade and disable Indonesia's trade relationship with other WTO trading partners.

\section{Context to the Emergence of the Halal Act}

Indonesia has one of the world's largest Muslim populations. ${ }^{5}$ Combined with one of the fastest growing middle class economies in the world, the increasing demand of the Indonesian population for higher standards of food cannot be overlooked. One of the primary challenges to the increased demand for trade coinciding with a majority religious community is the extent to which religious laws and principles influence consumer habits and trade policies. It is within this context that the Indonesian Halal Act has emerged, in an effort by the government to address the overlap of consumer preference driven by religious expectation and freedom.

Academic commentary on the new Halal Act is relatively sparse. So far, comments have come from law firms and chambers of commerce, likely in response to concern from international business. This analysis seeks to give due regard to the thought process of lawmakers at the time of enactment, in order to understand the context within the law emerges. The preamble to the law, as well as the concluding Explanation of the law, is useful for gaining perspective in this regard. This section will briefly consider some of the considerations stipulated at the beginning of the Halal Act, within the context of the concluding Explanation of the law, in order to ascertain the perspective of lawmakers in drafting the Halal Act.

The preamble to the Halal Act considers a number of factors taken into consideration at the outset and formulation of the Act. These include, first and foremost, that the Constitution of the Republic of Indonesia ensures the freedom of every citizen to practice his or her own religion. ${ }^{6}$ This is reinforced in the General Explanation written at the end of the legal document. The freedom of religion is an interesting concept to underpin the core of a law, enacted by a secular government, to apply to all trade in consumer products to, and within, the country. ${ }^{7}$ In mentioning the fundamental right to religious freedom, the drafters of the law appear to connect the facilitation of Halal certification to the freedom of religious practice enshrined in the Constitution. In doing so, the second consideration of the Halal Act stipulates that it is the role of the state to facilitate the free practice of religion by providing protections and assurance of

\footnotetext{
${ }^{5}$ World Bank, 'Country Statistics - Indonesia', http://data.worldbank.org/country/indonesia.

${ }^{6}$ Halal Product Assurance, Law No. 33 of 2014 [hereinafter Halal Act], Consideration A.

${ }^{7}$ Indonesian Halal Act, above n 6, at Article 4.
} 
the Halalness of a given product. ${ }^{8}$ The motivation to the law, then, could be described as not so much religious as it is legal; the state must protect the freedom of religion of its peoples (as per the Constitution) and thus enact a law to support the religious practice of Halal, through regulated certification and labeling. The question of whether such protection would also extend to certification requirements of religious minorities, say for instance the dietary requirements in Hinduism or Buddhism (religions that are also recognized in Indonesia), remains to be seen. Still, it is an important consideration that the drafters of the law seek to preserve religious freedom, rather than curb it.

Other considerations stipulated in the preamble of the Halal Act include a recognition that the current products circulating within Indonesia are not always guaranteed as Halal. ${ }^{9}$ This is reinforced by Article 3 of the Halal Act, where the Halal Product Assurance is tasked with the objective to 'providing convenience, security, safety, and certainty of the availability of Halal Product for the public in consuming and utilizing a Product. ${ }^{10}$

Currently, Halal compliance and food safety have government oversight as part of one overseeing program, the Safe, Healthy, Whole, Halal (Aman, Sehat, Utuh dan Halal) program that has provincial reach. ${ }^{11}$

There is at present, however, no central government legal oversight body, meaning that the coherent regulation of Halal products is, arguably, necessary to guarantee the Halalness of products labeled as Halal. ${ }^{12}$ Currently in Indonesia, Halal certification is generally problematic and inconsistent for fresh foods, particularly in wet markets. ${ }^{13}$ There are irregularities between Halal slaughterhouses and there have been instances of random checks conducted in wet markets where Halal procedures were not being followed. ${ }^{14}$ This is significant as according to the USDA, $88 \%$ of all retail food sales in Indonesia occur in wet markets. ${ }^{15}$ The Indonesian Ministry of Health places this number at $60 \%$ of the overall population. ${ }^{16}$ Gaps in Halal compliance mean that consumers cannot be completely sure that their food meets religious standards.

Considering only the above circumstances, namely the protection of religious belief and the necessity of consistent Halal labeling regulation, it is understandable that Indonesian decision makers felt the need to enact new legislation. What is problematic, however, is the extent to which lawmakers decided to impose Halal certification and labeling requirements. A number of provisions in the Halal Act suggest onerous labeling requirements and certification processes that raise issues of consistency with the WTO Technical Barriers to Trade Agreement, as well as posing potential barriers for the broader business landscape in Indonesia. These issues will be considered below after a look at the Halal Act provisions.

\footnotetext{
${ }^{8}$ Ibid, at Consideration B.

${ }^{9}$ Ibid, at Consideration C.

${ }^{10}$ Ibid, at Article 3.

${ }^{11}$ ASUH Media Center, 'Let's consume ASUH (Safe, Healthy, Whole, Halal) Meat', 9 September 2012, http://mediacenter.malangkota.go.id/2012/09/ayo-konsumsi-daging-asuh/\#axzz4BhpRRlkt.

${ }^{12}$ Indonesian Halal Act, above n 6, Consideration D.

13 Indonesian Ministry of Religious Affairs, 'Nora: 3 Main Challenges for Halal Certification in West Kalimantan', 28 March 2016, http://bimasislam.kemenag.go.id/post/berita/nora-tiga-permasalahan-utamasertifikasi-halal-bagi-ukm-pangan-di-kalimantan-barat-.

14 Indonesian Council of Ulama, 'Slaughterhouse Should Be Certified Halal', http://www.halalmui.org/newMUI/index.php/main/detil_page/8/1501.

15 John Dyck, Andrea E. Woolverton and Fahwani Yuliati Rangkuti, 'Indonesia's Modern Retail Sector: Interaction with Changing Food Consumption and Trade Patterns', USDA Economic Information Bulletin No. 97, June 2012, at 12.

${ }^{16}$ Application of the Ministry of Health Regulation No. 519/MENKES/SK/VI/2008 on Healthy Markets.
} 


\section{Overview of Halal Act Provisions}

There a number of striking provisions of the Halal Act that would potentially disrupt international trade and create uncertainty for business. Some of the wording of these provisions is problematic in their current form as they are unclear as to the extent of the reach of the Halal Act. Still, the implementing regulations are yet to be released and it may be that the dubious wording is clarified further. In any case, the potential scope of the law is enough to merit concern for trade liberalization.

\section{A. Mandatory Nature of the Halal Act}

Mandatory labeling requirements imposed on goods and services generally raise eyebrows, however this law concerns a subject that has previously remained voluntary. Indeed, in most WTO member states Halal labeling laws remain voluntary. Further, the question of whether a measure in mandatory is essential in determining the existence of a technical regulation, as per the TBT. Such a change in practice, then, merits further inspection.

Article 4 of the Halal Act maintains that products that enter, circulate and are traded in the territory of Indonesia 'must' be certified halal. Article 47(1) goes on to specify that Foreign Halal Products that are imported into Indonesia 'must' comply with provisions as regulated in this law. In both instances, the word 'must' (and its Indonesian equivalent wajib) is used to denote the mandatory nature of the Halal Act. This assertion is in line with interpretation of the meaning of mandatory from WTO jurisprudence.

In EC-Trademark and Geographical Indications (Australia), the Panel cited the New Shorter Oxford English Dictionary in order to define the ordinary meaning of the word mandatory. Accordingly, Mandatory was defined, in that instance, as 'obligatory in consequence of a command; compulsory. ${ }^{17}$ The choice of the word 'must' in the Halal Act contextually denotes a compulsory action. All products circulating and trading in Indonesia, whether foreign or domestic, are apparently required to be certified Halal. Additionally, the Panel in $U S-C O O L^{18}$ used two main indicators to determine that a measure could be considered mandatory. The first was considering the use of the word 'shall' and the second was the enforceability of the measure through specified sanctions. This same measurement could foreseeably, though not categorically, be used in relation to the Halal Act. While there are no clear sanctions for companies that do not certify their products as Halal, there are strict penalties, including large fines and criminal penalties, for companies that use the fraud Halal certificate/label to claim the Halalness. One way to see this is because the non-certified/labelled Halal products are not allowed to enter, circulate and traded in Indonesia pursuant to Article 4, unless they are certified or labelled. Thus, strict penalties are available for those who fraudulently use Halal labels.

A determination that the choice of wording in the Halal Act is mandatory would be further supported by EC-Asbestos, ${ }^{19}$ where the Appellate Body concluded that the phrase, 'all

\footnotetext{
${ }^{17}$ Panel Report, European Communities - Protection of Trademarks and Geographical Indications for Agricultural Products and Foodstuffs, Complaint by Australia, WT/DS290/R, adopted 20 April 2005, para 7.453.

18 Panel Reports, United States - Certain Country of Origin Labelling (COOL) Requirements, WT/DS384/R / WT/DS386/R, adopted 23 July 2012, para 7.160 [hereinafter Panel Report, US - COOL].

19 Appellate Body Report, European Communities - Measures Affecting Asbestos and AsbestosContaining Products, WT/DS135/AB/R, adopted 5 April 2001, para 72 [hereinafter Appellate Body Report, EC-Asbestos].
} 
products must not contain' was mandatory, leading to the Appellate Body finding that the regulation in question was indeed a technical regulation as per the TBT. Unless the drafters of the Halal Act paid no attention to prevailing WTO interpretation, it is likely that they intended the word 'must' to have mandatory implications.

In lieu of any implementing regulation, at present, and in light of the WTO jurisprudence, it is possible to interpret the Halal Act as a regulation with a mandatory nature. Mandatory labeling requirement, however, present a minefield when it comes to navigating international trade standards. On the one hand, they arguably protect consumer choice; on the other hand they potentially raise the price of goods and create non-tariff barriers to trade. ${ }^{20}$ Importantly, they also create potential obstacles to adhering to international trade law. A number of other provisions of the law are highlighted below to provide context for the trade liberalization alarm bells that this mandatory labeling law raises.

\section{B. Scope of Halal Products}

Article 4 plainly states that, 'products that enter, circulate, and traded in the territory of Indonesia must be certified Halal.' The definition of a product in the context of the Halal Act is defined in Provision Article 1(1) of the Act with very broad scope. That article states that, 'Products are goods and/or services that are related to food, beverage, drug, cosmetic, chemical product, biological product, genetically engineered product, as well as consumer goods that are worn, used, or utilized by the public. ${ }^{21}$

By including good and services, drugs, cosmetics, genetically engineered products and, particularly, consumer goods, the standard of Halal certification has increased to include almost all consumer goods, not only food. In addition to this, the inclusion of services in the definition of a product raises questions as to how a service can be certified Halal. Importantly, for the purposes of this paper, the sheer number and scope of products that must be certified Halal potentially poses a technical barrier to trade. Products that have hitherto been superfluous to Halal certification must now undergo an (unspecified) additional step that adds costs and hassle to importers.

\section{Organizational Oversight Structure}

Articles 5-16 put in place a government organization, the Halal Product Assurance Organizing Agency, (BPJPH) to oversee the Halal certification process, as well as stipulate the functioning of that organization and the scheme of coordination for the process of Halal certification. The law empowers the BPJPH to oversee Halal product assurance (JPH), formulate policy, issue and revoke Halal certification, certify Halal auditors, and register Halal certification for foreign products, among other things. ${ }^{22}$ They also specify terms of collaboration with government ministries and the Indonesian Council of Ulama (MUI). Included in the collaboration with the MUI is the certification of Halal auditors, the stipulation of the Halalness of a product and Halal Examination Agency (LPH) accreditation, as well as empowering the MUI to issue discretional Halal edicts in the form of Decree of Halal Product Stipulation. ${ }^{23}$ Below in Table 1 is a chart showing the organizational structure for Halal certification that the law creates.

\footnotetext{
${ }^{20}$ Colin A. Carter and Guillaume P. Gruère, 'Mandatory Labeling of Genetically Modified Foods: Does it Really Provide Consumer Choice?' 6 Journal of Agrobiotechnology Management and Economics 68 (2003).

${ }^{21}$ Indonesian Halal Act, above n 6, at Article 1.

${ }^{22}$ Indonesian Halal Act, above n 6, at Article 6.

${ }^{23}$ Ibid, at Article 10.
} 


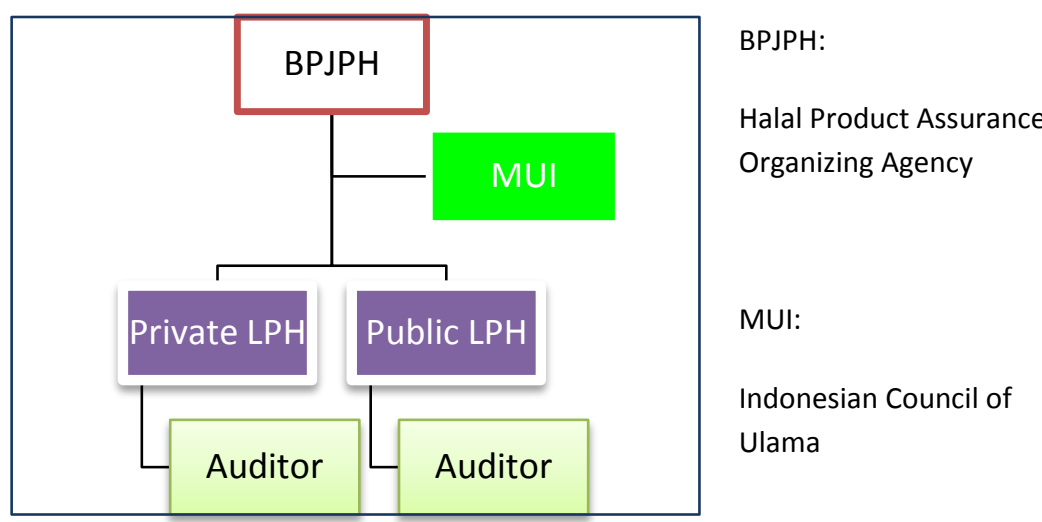

Table 1. Organizational structure for Halal Certification in Act No. 33 of 2014

At present, business operators intending to have their products certified Halal essentially do this voluntarily through the MUI. The new law, when completely implemented, will require a far more onerous process for Indonesian Halal certification that will be mandatory for almost all consumer products. This organizational structure requires the collaboration of at least four government and non-governmental agencies, not to mention the possibility of involvement from other ministries. Such a structure, at the outset of a new process for Halal certification, and more broadly when widely implemented to ensure Halal compliance could prove problematic. The bureaucracy involved in receiving certification through four or more agencies suggests an elongated technical process to Halal certification, and more hurdles for importers of consumer goods. It opens the door to rent-seeking practices and long delays to receive certification. Furthermore, the Halal Act provides no clear guidelines for the standards by which products will be determined Halal.

\section{Halal Logistics}

Also noteworthy is the requirement that the location, place and equipment of the production, processing and storing of goods be separate for Halal and non-halal products. ${ }^{24}$ Articles 21 and 25 seem to suggest that manufacturers of consumer products, such as clothing, must establish separate utilities for the production, processing and storing of goods, if they also manufacture goods that could be considered Haram, such as, for example animal fibers used in textiles from animals that have not been certified Halal.

Article 25 stipulates the technical requirements of the Halal Act. It states,

Business Operators that obtain Halal Certificate must:

a. attach the Halal Label on the Product that receive Halal Certificate;

b. maintain the halalness of the Product that has obtain Halal Certificate;

c. separate the location, place and equipment for processing, storing, packaging, distributing, selling, and presenting between Halal and non-halal Product;

d. renew the Halal Certificate if the validity period of the Halal Certificate has expired; and

e. report change of Material composition to BPJPH.

These conditions require Halal Labels to be placed on products receiving Halal certification, which is a straightforward requirement. However, taken in conjunction with Article 4, Halal labels would need to be placed on all consumer goods, from t-shirts to televisions. Many businesses may find such requirements alarming if they product consumer

${ }^{24}$ Ibid, at Article 21. 
goods that do not traditionally require halal labeling (i.e. non-food items).

\section{E. Non-Halal Products}

Article 26 extends the Halal labeling requirement to labeling for non-Halal products. Such an approach could be seen as a natural corollary to a law that requires mandatory Halal labeling, as non-Halal (or Haram) products would require differentiation. The article explains,

(1) Business Operators that produce Product from Material that originate from haram Material as intended in Article 18 and Article 20 is excluded from submitting Halal Certificate application.

(2) Business Operators as intended in paragraph (1) must attached non-halal information on the product.

There is no further clarification as to what the Haram label would entail, or the process for businesses to define material as Haram. Currently, there is a regulation from Foods and Drugs Agency (BPOM) saying business operators must affix a distinct label to inform consumers that the product contains non-halal materials. ${ }^{25}$ However, it is unclear whether this label will be used under the new Halal Act or a new label will be introduced.

Non-halalness determination for complex products such as cosmetics or medicines might be challenging. Particularly, the certification is intended for Halal products. How a business operator can know that their product in not Halal without submitting an application for a Halal determination remains to be seen.

\section{F. Procedures}

Articles 29-45 stipulate the formal procedure by which Halal certification will be sought upon implementation of the Halal Act. While the procedure presently takes an average of 75 days, ${ }^{26}$ the new procedures will add at least 42 days to the process of certification. This is outlined in Table 2 below.

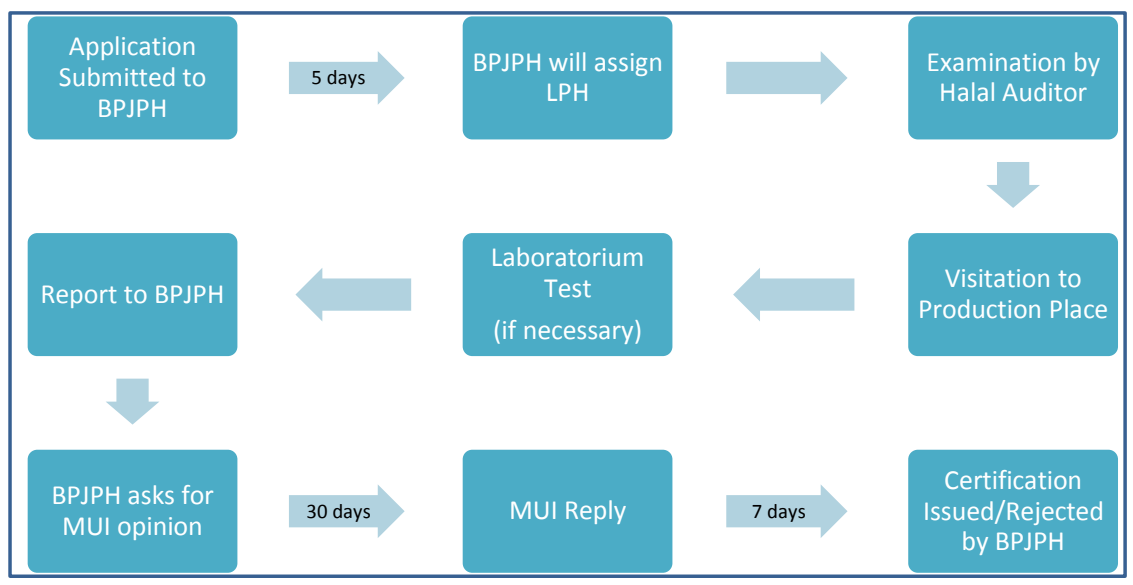

Table 2. Certification process under the new law

For business, a longer processing time may correlate to higher costs, particularly if goods must be periodically checked. Higher costs may also arise from place of production checks from

\footnotetext{
${ }^{25}$ Regulation of Indonesian Food and Drugs Agency No. HK.00.05.1.23.3516 concerning Marketing Approval for Medicine, Traditional Medicine, Cosmetics, Food Supplement and Food Originating or Containing Certain Substances and or Containing Alcohol, Article 6.

${ }^{26}$ Based on the authors interview with Vice Director of the Assessment Institute for Foods, Drugs and Cosmetics, the Indonesian Council of Ulama on January 2016.
} 
several oversight bodies. Indeed, a Formal Meeting on certification practices at the WTO in 2013 concluded with member-states agreeing that processes for certification must be streamlined in order to reduce cost and time to market. ${ }^{27}$ Higher costs mean less comparative advantage to sell to the Indonesian market and potentially more expensive final products passed on to consumers. ${ }^{28}$ In a world of increasing completion standards and their procedures need to be made as simple as possible to facilitate economically affordable access by small and large business alike. ${ }^{29}$ Ideally, these processes should occur before a product leaves the exporting country. ${ }^{30}$ However, this seems almost impossible under the Halal Act where four separate government and non-governmental organizations have a hand in the procedural steps. Simplifying the certification process is important for the benefit of both producers and Indonesian consumers, and imperative to upholding Indonesia's obligations under WTO law.

\section{G. Halal Label}

Articles 38-39 further explain the technical requirements for Halal packaging and labeling. They require that, upon Halal certification, the Halal label is placed on the 'product packaging, on a specific part of the product and/or on a specific place on the product. ${ }^{31}$ They also specify that the label, 'must be easy to see and read as well as not easily erase[able], detach[able], and damage[able]'. ${ }^{32}$ These requirements suggest a type of label that is printed directly on a product's package, as a sticker could foreseeable detach or be removed. To require that all products have a Halal label printed directly on the product would suggest changes to the manufacturing process and would make it onerous for businesses intending to sell products in multiple markets to create Indonesian specific products.

The requirements of the Halal Act discussed in this section give rise to questions of compliance with the TBT, as well as the overall certainty of Indonesian trade regulations for importers. The following sections will consider these elements.

\section{The Application of WTO Law}

In determining the WTO consistency of the Halal Act, the central question is whether the measures in the Act are trade barrier. As corollaries, questions related to discrimination caused the labeling itself, the necessity of the measure, reference to international standards and whether the measure constitutes an unnecessary barrier to trade are also relevant.

In measuring the consistency of the Halal Act with WTO law, it may be possible to evoke more than one international trade agreement. One may refer to the application of Sanitary and Phytosanitary Measures (SPS) Agreement. This paper argues that the SPS agreement does not apply to the Halal Act. The primary argument in this regard is that there can be no clear scientific correlation between Halal products and the health and safety of consumers. Rather, the provisions of the Halal Act present issues that fall under the ambit of the TBT agreement, creating requirements that relate to technical regulations for Halal and non-Halal products.

\footnotetext{
27 WTO Secretariat, 'Members Grapple with Certifying Products, and Certifying the Certifiers'. https://www.wto.org/english/news_e/news13_e/tbt_29oct13_e.htm.

28 Richard Bonsi, A.L. Hammett and Bob Smith, 'Eco-Labels and International Trade: Problems and Solutions' 42(3) Journal of World Trade 407 (2008), at 419.

${ }^{29}$ Ibid, at 427.

${ }^{30}$ WTO News, above n 27.

${ }^{31}$ Indonesian Halal Act, above n 6, at Articles 38 and 39.

${ }^{32}$ Ibid.
} 


\section{A. SPS or TBT?}

When lawmakers of the Halal Act sight public health reasons for its enactment, it may be tempting to focus attention of the SPS. Indeed, the Codex connected to the SPS refers in section 4.2 that, in accordance with the Codex General Guidelines on Claims, claims on Halal should not be used in ways which could give rise to doubt about the safety of similar food or claims that Halal foods are nutritionally superior to, or healthier than, non-Halal foods. In fact, the misuse of Halal labeling is cited throughout the Halal Act. However, distinction must be made between the application of the SPS and TBT agreements: the scopes of the SPS and TBT agreements are different. The SPS agreement covers measures with a purpose to protect, (1) human or animal health from food-borne risks; (2) human health from animal- or plant-carried diseased; (3) animals and plants from pests or diseases; and (4) the territory of a country from other damage caused by the entry or spread of pests. ${ }^{33}$ The TBT agreement, on the other hand covers technical regulations and voluntary standards and procedures, including labeling. ${ }^{34}$ Moreover, Article 1.5 of the TBT Agreement clearly specifies that provisions of the Agreement do not apply to sanitary and phytosanitary (SPS) measures.

Non-Halal food should not be claimed to cause problems to human health. So, the measures affecting Halal certification/labeling may initially appear a straightforward application of the TBT. Should Indonesia ever be challenged on the Halal Law, it would be difficult, if not impossible, for them to make a scientific correlation between the health of their citizens and the consumption of Halal products, beyond faith-based belief. If Halal labeling derives fundamentally from a belief, it could not be measured by the standards of natural scientific inquiry. In this respect, the issues of sanitary and phytosanitary measures are not applicable to the Halal Act.

Notwithstanding the little chance that SPS arguments are likely to have, this opens to the realm of international trade a very sensitive and deeply personal issue about a set of standards that derive little basis in objective terms. In that sense, through fundamentally different, it echoes the debates around genetically modified food (GMO) that were considered in the WTO $E C$ - Biotech dispute. In that instance, the United States argued that there was no scientific evidence establishing justification for anti-GMO measures ${ }^{35}$, placing the question of GMO labeling under the mandate of the TBT.

\section{B. An examination of the TBT consistency of the Halal Act}

There is no single way to implement the TBT agreement, and each measure in question must be considered on its own merits. ${ }^{36}$ Over the twenty years of the TBTs existence, however, some patterns have emerged. A starting point for the Halal Act is whether the measures are technical barriers to trade, defined in Annex 1 of the agreement, that are generally understood to invoke the TBT.

\footnotetext{
${ }^{33}$ WTO Agreement on the Application of Sanitary and Phytosanitary Measures (SPS Agreement), Annex A.

${ }^{34}$ Melvin Spreij, 'The SPS Agreement and Biosafety', 65 FAO Legal Papers Online, March 2007, http://www.fao.org/3/a-bb098e.pdf.

35 Panel Reports, European Communities - Measures Affecting the Approval and Marketing of Biotech Products, WT/DS291/R, Add.1 to Add.9 and Corr.1 / WT/DS292/R, Add.1 to Add.9 and Corr.1 / WT/DS293/R, Add.1 to Add.9 and Corr.1, adopted 21 November 2006, para 4.570.

36 WTO Secretariat, 'Technical Barriers to Trade: Reducing Trade Friction from Standards and Regulations', 2015, https://www.wto.org/english/thewto_e/20y_e/tbt_brochure2015_e.pdf.
} 


\section{The Halal Act constitutes a Technical Regulation}

The starting point to consider when assessing if the Halal Act constitutes technical barriers to trade is to ascertain whether the law is a technical regulation as defined in Annex 1.1 of the TBT. That definition specifies 'document which lay down product characteristics or their related processes and production methods, including the applicable administrative provisions, with which compliance is mandatory. It may also include or deal exclusively with terminology, symbols, packaging, marking or labeling requirements as they apply to a product, process or production method. ${ }^{37}$

In further determining whether the law constitutes a technical regulation, WTO jurisprudence provides significant insight. In EC - Asbestos,${ }^{38}$ a three-tiered test was construed to help determine a technical regulation. This included whether:

1. The measure applies to an identifiable product of group of products;

2. The measure lays down product characteristics; and

3. Compliance with the product characteristics laid down in the measure are mandatory.

The Panel and Appellate Body in the subsequent cases recalled this test. For example, the panel in $U S-C O O L$ held that the United States' country of origin labeling measure is a technical regulation because the measure is mandatory (the word 'shall' and the enforcement mechanism including fine for each violation); it identifies product or a group of products, muscle cuts or in ground form beef or pork; and it lays down product characteristics by requiring a country of origin label to be placed on the identified products. ${ }^{39}$

All three of these elements are met within the framework of the Halal Act. The Halal Act has a wide-ranging scope that, in lieu of any implementing regulations, appears to cover all consumer products. ${ }^{40}$ This could, arguably, make it difficult to establish an identifiable group of products. However, the distinction between 'Halal' and 'non-Halal' (Haram) products throughout the Halal Act suggests that there are quantifiable products that are excluded from identification, thus creating an identifiable groups of products, being Halal. Beyond this, there are a number of provisions in the Halal act that set out the way in which compliance with the product characteristics (being Halal) are to be carried out and applied in a mandatory manner. Articles 26, 38 and 29 of the Halal Act specify the technical requirements of the Halal labeling, such as labels that cannot be removed, and include conditions that the production facilities must be separate from non-Halal product production. The technical regulations imposed by the Halal Act also echo the regulation deliberated in EC-Asbestos where the Appellate Body considered the phrase, 'all products must not contain asbestos fibers. ${ }^{41}$ Article 4 of the Halal Act does not use the negative wording in EC-Asbestos, or the encompassing term 'all', but affirms that, 'products that enter, circulate, and traded in the territory of Indonesia must be certified Halal.' It could be argued that Article 4 implies the term 'all products that enter Indonesia must not be Haram.' The mandatory nature of the Halal labeling, as per the Halal Act, suggests a technical regulation is in place. The mandatory element of a regulation was established in $U S-C O O L$, where the Panel considered the word 'shall' in the technical regulation, as well as the enforceability of the measure. ${ }^{42}$ The Halal Act uses terminology, such as 'shall' that reflects the

\footnotetext{
${ }^{37}$ WTO Agreement on Technical Barriers to Trade (TBT Agreement), Annex 1.1.

${ }^{38}$ Appellate Body Report, EC - Asbestos, above n. 19, at paras. 66-70.

${ }^{39}$ Panel Reports, US - COOL, above n 18, at paras. 7.156-62; 7.200-8; 7.211-17.

${ }^{40}$ Indonesian Halal Act, above n.6, at Article 4.

${ }^{41}$ Appellate Body Report, EC - Asbestos, above n. 19, at para 72.

${ }^{42}$ Panel Reports, US - COOL, above n 18, at para 7160.
} 
mandatory nature of the measure. In a further suggestion of the severity of non-conformity with the provisions of the Act, administrative sanctions are imposed for businesses that breach the terms of the Halal Act; ${ }^{43}$ the final section of the Explanatory Notes attached to the Halal Act even go so far as mentioning that, administrative and criminal sanctions are enforced for violation of the law. ${ }^{44}$ The severity of non-compliance, coupled with the mandatory nature of the labeling requirements and the distinct characterization of the relevant products all point to classification of the package of mandatory labeling provisions of the Halal Act as a technical regulation.

Being a technical regulation, the Halal Act distinctly falls under the ambit of the TBT. As such, there are several provisions of the TBT that the Halal Act potentially contradicts. These include discrimination, trade restrictiveness, overlooking international standards and other WTO state practice and, taking into account conformity assessment, the procedural obstacles to trade. Arguments for each of these are elaborated below. Some are, admittedly, more tenuous to establish than others, but when these TBT provisions are measured individually and as a whole, there is little doubt that the Halal Act flouts established international trade law.

\section{Non-Discrimination - TBT Article 2.1}

Avoiding trade discrimination is a widely recognized goal of the WTO legal system. ${ }^{45}$ Article 2.1 of the TBT stipulates that, in respect of technical regulations, imported products 'shall be accorded treatment no less favorable than that accorded to like products of national origin and to like products originating in any other country. ${ }^{46}$

Article 2.1 is similar to Article III:4 (national treatment) and Article I:1 (most-favorednation/MFN) of the GATT. The Appellate Body in US - Clove Cigarettes acknowledged that the very similar formulation of the provisions, and the overlap in their scope of application demonstrate that Article III:4 provides relevant context in interpreting Article 2.1. ${ }^{47}$ But it is important to note that their scope, content and obligations (TBT Article 2.1 and GATT Articles I:1 and III:4) are not the same or substantially the same, as found by the Appellate Body in US Tuna II (Mexico). ${ }^{48}$

There is also no a general exceptions clause akin to Article XX of the GATT in TBT Agreement. ${ }^{49}$ But, Voon, Mitchell and Gascoigne note that the Appellate Body uses some language of the GATT Article XX chapeau in applying TBT Article 2.1 and uses some of the techniques it uses in applying the word 'necessity' in GATT Article XX (a), (b) and (d) in applying TBT Article 2.2. ${ }^{50}$

\footnotetext{
${ }^{43}$ Indonesian Halal Act, above n 6, at Articles 41 and 48.

${ }^{44}$ Ibid, at Explanation item 7.

45 Thomas Cottier, Petros C. Mavroidis, Patrick Blatter, Regulatory Barriers and the Principle of Nondiscrimination in World Trade Law, (Michigan: University of Michigan Press, 2000) 84.

${ }^{46}$ TBT Agreement, Article 2.1.

47 Appellate Body Report, United States - Measures Affecting the Production and Sale of Clove Cigarettes, WT/DS406/AB/R, adopted 24 April 2012, para 100 [hereinafter Appellate Body Report, US Clove Cigarettes).

${ }^{48}$ Appellate Body Report, United States - Measures Concerning the Importation, Marketing and Sale of Tuna and Tuna Products, WT/DS381/AB/R, adopted 13 June 2012, para 405 [hereinafter Appellate Body Report, US - Tuna II (Mexico)].

${ }^{49}$ Appellate Body Report, US - Clove Cigarettes, above n 46, at para 101.

50 Tania Voon, Andrew Mitchell and Catherine Gascoigne, 'Consumer Information, Consumer Preference and Product Labels under the TBT Agreement' in Tracey Epps and Michael J Trebilcock (eds), Research Handbook on the WTO and Technical Barriers to Trade (Cheltenham: Edward Elgar, 2013), 454-84 at 457. Although they also point out that the contents of and relationship between TBT
} 
The Appellate Body also noted that Article 2.1 of the TBT prohibits both de facto and de jure discrimination. ${ }^{51}$ Article 2.1 does not prohibit detrimental impact (discrimination) that 'stems exclusively from a legitimate regulatory distinction. ${ }^{, 52}$ In $U S-C O O L$, the Appellate Body agreed with the panel's finding regarding the legitimacy of objective pursued by the US country of origin labelling (COOL) measure, namely to provide consumers with information on the countries in which the livestock from which the meat they purchase is produced were born, raised, and slaughtered. ${ }^{53}$

The Halal law requires that a Halal label be affixed to the product that has been approved by the BPOM and endorsed by the MUI. ${ }^{54}$ In other words, the required label itself is not one that generally distinguishes the product as Halal, but one that has been approved by the Indonesian Halal certification authorities. Labels from Halal certification authorities outside Indonesia are not accepted under the law, except where special permission has been granted by the MUI.

The distinction between labels becomes problematic when products are imported into Indonesia that have already been approved as Halal overseas. Added burden is placed on producers and distributors that go beyond the necessity of providing consumers with reassurance that a product is Halal. It adds another level of onerousness to the mandatory Halal labeling in specifying a Halal label distinct from other Halal labels for the Indonesian market. In the midst of this problem is the question of discrimination. In this respect, the extent to which favor is given to domestic Halal labeled products, versus internationally Halal labeled products, becomes a cause for concern. In practice, there are minor differences among Halal standards adopted by countries. ${ }^{55}$ Halal standards are basically similar in essence as they are sourced from the Koran.

What is important to consider, in any case, is weather the labeling itself creates a distinction between imported and domestic products that adds an unnecessary and discriminatory barrier to trade. Should the Indonesian Halal Act be challenged, the complainant may argue that the moral/religious objective is not the driving force behind it, thus such distinction accords no less favorable treatment to like (Halal certified) imported products, and amounts to arbitrary and unjustifiable discrimination.

\section{More trade restrictive than necessary - TBT Article 2.2}

Beyond the challenge of discrimination, another consideration of consistency with TBT provisions is apparent in Article 2.2. This article establishes that, 'technical regulations shall not be more trade-restrictive than necessary to fulfill a legitimate objective, taking account of the risks non-fulfillment would create.'

The Article goes on to suggest what constitutes a legitimate objective, 'inter alia: national security requirements, the prevention of deceptive practices and the protection of

Articles 2.1 and 2.2 'does not align precisely with the analytical approached' adopted by the Appellate Body related to the chapeau and respective subparagraphs of Article XX.

${ }^{51}$ Appellate Body Reports, United States - Certain Country of Origin Labelling (COOL) Requirements, WT/DS384/AB/R / WT/DS386/AB/R, adopted 23 July 2012, DSR 2012: V, para 269 [hereinafter Appellate Body Report, US - COOL]; Appellate Body Report, US - Clove Cigarettes, above n 46, at para 181.

${ }_{52}$ Appellate Body Report, US - Clove Cigarettes, above n 46, at para 181.

${ }^{53}$ Appellate Body Report, US - COOL, above n 50, at para 453.

${ }^{54}$ Indonesian Halal Act, above n 6, at Article 47.2.

55 Florence Bergeaud-Blackler, Johan Fischer, John Lever, Halal Matters: Islam Politics and Markets in Global Perspective, (Oxford: Routledge, 2015), 5; Halal Malaysia, Malaysian Standard on Halal Food, http://www.Halal.gov.my/v4/index.php/en/garis-panduan/standard-malaysia; Lukmanul Hakim, 'Halal Certification in Indonesia', https://www.austrade.gov.au/ArticleDocuments/1418/IABW_PFB_LPPOMMUI.pdf.aspx. 
human health or safety, animal or plant life or health, or the environment. ${ }^{56}$ Considering the context of the Halal Act, public morals or protection of religious beliefs could be argued as the legitimate objective. However, Article 2.2 does not comment on religious practice or belief of the population, something that runs central to the establishment of the Halal Act. However as will be explained below, WTO case law has acknowledged that the phrase 'inter alia' means that the list of objectives provided in Article 2.2 is not an exhaustive list and that legitimate objective can include protection of religious beliefs and public morals.

In conducting Article 2.2 analysis, a panel should consider: '(i) the degree of contribution made by the measure to the legitimate objective at issue; (ii) the trade-restrictiveness of the measure; and (iii) the nature of the risks at issue and the gravity of consequences that would arise from non-fulfilment of the objective(s) pursued by the Member through the measure. ${ }^{57}$ In most cases, the analysis will also include a comparison between the measure at issue and a possible alternative measure. ${ }^{58}$

The Appellate body in US - Tuna II (Mexico) examined the elements of the term, 'restrictive'. They found that a technical regulation is restrictive if it provides a limitation on action. In the case of the Halal Act, what can be considered limiting is the mandatory nature imposed upon businesses to not only register products as Halal, but also Haram. The broad scope of the measure appears to apply to almost any consumer product imaginable, thus creating a significant shake-up of trade procedures. Indeed, the mandatory element of the Halal Act could produce a barrier for importers, especially smaller operations, who do not have the means by which to transform whole production and distribution chains to suit the labeling, production, storage and transportation requirements that the Halal Act calls for. Furthermore, it is unclear from the Halal Act and its general explanations, why a blanket mandatory requirement is necessary to achieve the objective of facilitating religious freedom.

The availability of the less burdensome measure that serves the similar level of contribution to the intended objective would undermine Indonesia's defense of the necessity of its measure. A complainant to Indonesian Halal measures might propose a number of alternative measures. One of them is possibly voluntary Halal certification. The mandatory scheme may keep or force those who cannot afford it out of the market. Under the voluntary certification scheme, producers and retailers could either opt for certification by the Halal authority (thereby they can use the official Halal label) or marketing their products with a (non-official) 'Halal' or 'Non-Halal' label with the monitoring of government. Without diminishing the importance of Halal certification, both Halal and Haram products can coexist, with the ultimate decision to purchase either product being left to the Indonesian consumer.

\section{International standards - TBT Article 2.4}

Another relevant article is Article 2.4, requiring that member states use international standards as a basis for their own technical regulations, where they exist. ${ }^{59}$ The exception to this is noted in situations where the measures are 'ineffective or inappropriate' for the achievement of legitimate objectives. ${ }^{60}$

\footnotetext{
${ }^{56}$ TBT Agreement, Article 2.2.

${ }^{57}$ Appellate Body Report, US - Tuna (II) (Mexico), above n 47, at para 322.

${ }^{58}$ Ibid.

${ }^{59}$ TBT Agreement, Article 2.4.

${ }^{60}$ Ibid.
} 
Currently, several international bodies are struggling to unify the Halal standards between countries. Organization of Islamic Countries (OIC) kicked off its effort to create Halal standards on food and cosmetics on 9 December $2015 .^{61}$

Another international standard setting body, striving for international Halal standards is the International Organization for Standardization (ISO). In October 2015, the United Emirates Arab (UEA) proposed to the ISO to establish a technical committee on Halal activity on goods and services. ${ }^{62}$ If this proposal succeeds, the standards issued by the technical committee will be crucial for the WTO on Halal issues, as the TBT Agreement has directly cited ISO in its Annex. The efforts to make a unification in Halal standards are remain to be seen.

Codex Alimentarius, another relevant internationally recognized standard, contains the General Guidelines for Use of the Term 'Halal' (the Codex). Importantly, WTO law recognizes the Codex Alimentarius as an international standard. While SPS Agreement makes an explicit reference to the Codex ${ }^{63}$ WTO jurisprudence indicates that the Codex is also applied to TBT. ${ }^{64}$

In its statement to the TBT Working Committee in March 2016, Indonesia explicitly stated that the provisions of the Halal Act are formulated based on the Codex. ${ }^{65}$ Such reference and acknowledgement demonstrates that Indonesia recognizes the Codex as the relevant international standard for Halal.

However, several provisions in the Halal Act are seemingly not in line with the Codex. Indonesian Halal Act prohibits Halal and non-Halal products to be processed in the same location, even with using separate facilities. ${ }^{66}$ In opposite, the Codex allows halal food to be prepared, processed or stored in different section or lines, but within the same premises, as long as necessary measures are taken to prevent contact between Halal and non-Halal foods. The Codex also allows facilities which have been used for non-Halal foods to be used for Halal foods provided that proper cleaning according to Islamic requirements have been done. ${ }^{67}$

Indonesia could argue that taking into account the risk of contamination, it adopts a measure that goes beyond the minimum standard provided in the Codex to ensure greater achievement to Indonesian Halal Act objective. The complainant may argue otherwise. Certain articles of the Halal Act that require excessive certification and labeling requirement and a giant swath of consumer products are overtly more trade restrictive than necessary.

\section{The possibility of Public Morals exceptions to the Halal Act}

Halal certification/labeling involve a level of belief and public perception that makes its mandatory nature particularly novel. The lawmakers who enacted the Halal Act may indeed be responding to a legitimate public concern. It is not unusual that states invoke religious beliefs or public morals justification to restrict their imports. Israel prohibits the importation of nonkosher meat or meat product, a number of countries put the ban on pornographic materials,

\footnotetext{
${ }^{61}$ Organization of Islamic Countries, 'Forum on unifying halal standards and procedures kicks off at OIC General Secretariat, Jeddah', http://www.oic-oci.org/oicv3/topic/?t_id=10714\&ref=4218\&lan=en.

${ }^{62}$ American National Standards Institute, 'ANSI Seeks Comments on Proposed New ISO Field Activity on Halal', https://www.ansi.org/news_publications/news_story.aspx?menuid=7\&articleid=df7e2813a4c8-4992-a59c-6109c8c8f52a.

${ }^{63}$ Preamble to the SPS Agreement.

${ }^{64}$ Panel Report, European Communities - Trade Description of Sardines, WT/DS231/R and Corr.1, adopted 23 October 2002, para 7.139.

${ }^{65}$ WTO, Statement by Indonesia to the Committee on Technical Barriers to Trade, G/TBT/W/443, 9-10 March 2016, point 1d.

${ }^{66}$ Indonesian Halal Act, above n. 6, at Article 21.

${ }^{67}$ Codex Alimentarius, 'General Guidelines for use of the Term 'Halal' GAC/GL 24-1997', Article 2.2.
} 
Taiwan imposes the ban of the sale of dog meat, and the EU prohibits the importation of seal products.

As such, it could be argued that Indonesia has the sovereign right to restrict trade for legitimate policy objective. This poses an interesting challenge. On the one hand, the WTO, appropriately, is not concerned with interfering in questions of religion and belief and must recognize the regulatory autonomy that Indonesia has as a member state. On the other hand, WTO members have agreed not to enact technical measures that are an unnecessary barrier to trade. Indonesia, thus, may have grounds to mount an argument that exception should be granted to the Halal Act on points of inconsistency with the TBT. Effectively, Indonesia could argue that a public morals exception exists.

\section{Public Morals - GATS Article XIV(a), GATT Article XX(a) and TBT}

Under the general exceptions stipulated in Article XX of the GATT 1994, subsection (a) allows for measures necessary for the protection of public morals. The concept of 'public morals' has been looked at in US - Gambling and China - Audiovisuals. According to the panel in the USGambling dispute (which concerned the similar concept of 'public morals' stipulated in Article XIV of GATS), public morals exception must be aimed at protecting the interests of the people within a community or a nation as a whole. ${ }^{68}$ The Panel considers the term 'public morals' denotes 'standards of right and wrong conduct maintained by or on behalf of a community or a nation. ${ }^{69}$ The panel in China - Audiovisuals reiterated the meaning of the term 'public morals' in US - Gambling and recognized that 'Article XX(a) uses the same concept as Article XIV(a), and see no reason to depart from the interpretation of 'public morals' developed by the panel in US - Gambling'. ${ }^{70}$

As pointed out by the Appellate Body in US - Clove Cigarettes, TBT Agreement contains no general exceptions clause akin to Article XX of the GATT or no explicit reference to public morals. ${ }^{71}$ However, the Preamble to the TBT Agreement has reflected the balance between trade-liberalization objective and Member's right to regulate. Moreover, when considering the word 'legitimate objective' in the context of Article 2.2, the Appellate Body in the US - Tuna (II) (Mexico) noted that the use of the words 'inter alia' in Article 2 suggests that the provision includes an open-ended list of legitimate objectives. ${ }^{72}$ The Appellate Body stated further that objectives recognized in other covered agreements may provide guidance for the analysis of what might be constituted as a legitimate objective under Article 2.2. ${ }^{73}$ The panel in EC - Seal Products recognized the public moral concern on seal welfare (the stated objective of the EU's measure) is legitimate under Article 2.2 of the TBT Agreement. ${ }^{74}$

In this sense, the protection of religious beliefs could be a legitimate objective. Public morals here would reflect the intention of the drafters of the Halal Act in protecting religious freedom as enshrined in the Indonesian Constitution. Accordingly, Indonesia can invoke Article

\footnotetext{
${ }^{68}$ Appellate Body Report, United States - Measures Affecting the Cross-Border Supply of Gambling and Betting Services, WT/DS285/AB/R, adopted 20 April 2005, para 6.463.

${ }^{69}$ Ibid, at para 6.465.

${ }^{70}$ Panel Report, China - Measures Affecting Trading Rights and Distribution Services for Certain Publications and Audio-visual Entertainment Products, WT/DS363/R and Corr.1, adopted 19 January 2010, para 7.759.

${ }_{71}^{7}$ Appellate Body Report, US - Clove Cigarettes, above n 46, at para 101.

${ }_{72}$ Appellate Body Report, US - Tuna (II) (Mexico), above n 47, at para 313.

73 Ibid.

${ }^{74}$ Panel Reports, European Communities - Measures Prohibiting the Importation and Marketing of Seal Products, WT/DS400/R and Add.1 / WT/DS401/R and Add.1, adopted 18 June 2014, para 7.419.
} 
2.2 to defend its Halal Act measures arguing that the measures are necessary to achieve its legitimate objective goal: public morals and protection of religious belief.

\section{Recommendations}

The attention given to the Halal Act in reports or notes issued by various chambers of commerce, as well as international law firms advising corporate clients, suggests concern across the board by international business. ${ }^{75}$ At the same time, it is worrisome for businesses within Indonesia too, that they will theoretically need to undergo the same level of burdensome scrutiny on all their consumer products. More than a simple endorsement process, the potential bureaucratic hurdles that the Halal Act creates, through numerous overseeing bodies, may be troublesome for business to navigate. Beyond this, the requirements to label non-Halal products as haram, and the ambiguity around the reach of products affected by the Act, create uncertainties that could put exporter to Indonesia in limbo in 2019.

The alternative to this is not necessarily keeping the status quo, where only one private entity has complete control over the entire Halal certification. However, domestic business and investment environment as well as Indonesia's WTO commitments should be rightfully taken into consideration in the drafting of laws like the Halal Act.

Alternatives may include, as a start, amending or clarifying Article 4 of the Halal Act, which is too broad. In lieu of this, a simple and effective system of non-mandatory Halal labeling should be devised that is less trade restrictive and provides a 'one-stop-shop' type of certification procedure for importers. This could be achieved through government oversight that is transparent, straightforward and simple. In doing this, the scope of products to be labeled Halal should be more clearly defined and an all-encompassing standard that takes into consideration global Halal standards should be developed, so that consumers and businesses can easily measure the Halalness of a given product.

Ultimately, nothing short of an international standard for Halal certification would provide businesses around the world the environment of consistency and assurance that is conducive to the facilitation of trade. The movement towards uniting standards for Organization of Islamic Countries (OIC) and Muslim majority countries worldwide is a welcome ideal in this regard. As one of the most populous Muslim nations in the world, Indonesia should seek to align itself with, and even lead, the process of global Halal standard harmonization. In doing so, the importance of implementing Halal labeling is not undermined and the flow on effect on businesses and trade will ultimately benefit Indonesian consumers. In this regard, the place of the moral values of populations can be retained while simultaneously improving trade-related activities.

\footnotetext{
${ }^{75}$ For example, American Chamber of Commerce in Indonesia, 'Indonesia's Halal Food Law: Pros and Cons', 18 December 2014, http://www.amcham.or.id/fe/4839-indonesia-s-Halal-food-law-pros-and-cons; Hadiputranto, Hadinoto \& Partners, 'Halal Product Assurance Law', January 2015 http://www.bakermckenzie.com/files/Publication/629bc003-3d3a-4bc5-9ddcd4377cd2457e/Presentation/PublicationAttachment/bff3c191-f135-4fbe-b2d0dfc9e7da2c26/al_jakarta_Halalproductassurance_jan15.pdf.
} 